\title{
Effects of Foliar Nutrition on Onion Seed Storage under Controlled Atmosphere
}

\author{
Shehata, S. A. ${ }^{1}$, Hashem, M. Y. ${ }^{2}$, Mahmoud, G. I. ${ }^{3}$, Abd El-Gawad, K. F. ${ }^{1}$, El-Ramady, H. R.*4,5 \\ Alshaal, T. A. ${ }^{4,5}$, Domokos-Szabolcsy, É. ${ }^{5}$, Elhawat, N. ${ }^{5,6}$, Prokisch, J. ${ }^{7}$ and Fári, M. ${ }^{5}$ \\ (1) Vegetable Crops Dept., Faculty of Agriculture, Cairo University, Egypt \\ (2) Economic Entomology Dept., Faculty Agriculture, Cairo University, Egypt \\ (3) Biochemistry Dept., Faculty of Agriculture, Cairo University, Egypt \\ (4) Soil and Water Sciences Dept., Fac. of Agriculture, Kafrelsheikh Uni., Kafr El-Sheikh, Egypt \\ (5) Plant Biotechnology Dept., Debrecen Uni., Böszörményi Ú. 138, 4032 Debrecen, Hungary \\ (6) Biological and Environmental Sci. Dept., Faculty of Home Economics, Al-Azhar University, Egypt \\ (7) Bio- and Environmental Enegetics Inst., Debrecen Uni., Böszörményi Ú. 138, 4032 Debrecen, Hungary
}

*Corresponding author: El-Ramady, H. (ramady2000@gmail.com)

\begin{abstract}
Summary: Storage of fresh fruits and vegetables prolongs their usefulness. The principal goal of storage is to preserve the commodity in its most useable form for the consumer. The extension of storage life and the improvement of quality of fresh fruits and vegetables can be supplied by harvesting at proper maturity, control of post-harvest diseases, chemical treatments, refrigeration, controlled and modified atmospheres. Two successive winter seasons of 2008/2009 and 2009/2010 were conducted under sandy soil conditions to study the effect of spraying with 12 commercial compounds on onion seeds and storage under controlled atmosphere. The germination percentages were $85.50,86.85,83.75$ and 82.15 for CA1, CA2, CA3 and CA4, respectively. Water content of onion seeds was significantly increased with decreasing storage temperature in all controlled atmospheres. Water content values were 4.48, 4.40, 4.55 and 4.54 for CA1, CA2, CA3 and $\mathrm{CA} 4$, respectively. There were significant decreases in water content with increasing exposure periods. The lowest water content was recorded for the exposure periods of 120 and 240 days. Catalase and peroxidase activities were decreased with the decreasing of storage temperature, whereas malondialdehyde content was increased. The exposure for 120 days recorded the highest catalase activity. The highest value of peroxidase (11.72) was recorded for CA2. Peroxidase activity increased as exposure period increased until 120 days and then decreased. Cold storage temperature $\left(5^{\circ} \mathrm{C}\right)$ showed the highest malondialdehyde content followed by room temperature. The CA2 showed the lowest malondialdehyde content compared with other controlled atmospheres. The exposure period of 120 days had the lowest malondialdehyde content.
\end{abstract}

Keywords: Onion; pre-harvest; post-harvest, seeds production, storage under controlled atmosphere

\section{Introduction}

It is well known that, fresh fruit and vegetables are living tissues that continue to lose water after harvest, but, unlike growing crops, they can no longer replace lost water from the soil and must rely on the water content present at harvest. The loss of water from fresh produce following harvest is a serious problem because it causes shrinkage and weight loss. Most commodities become unsalable as fresh produce after losing 3-10\% of their weight (Ben-Yehoshua and Rodov, 2003). The quality and storage life of fresh fruits and vegetables are highly dependent upon the vapor pressure gradient between the produce and the storage atmosphere. Therefore, when the produce and the storage environment are maintained at the same temperature (assuming factors such as air velocity are held uniform), the transpiration rate is highly correlated with the relative humidity $(\mathrm{RH})$ during storage time. For the commodity's transpiration, however, a high RH storage environment plays an important role in maintaining the quality of produce. Recommended RH levels for the storage of fresh fruit and vegetables are commodity specific, with levels generally in the range of 85-95\% (Hung et al. 2011).

Onion (Allium cepa L.) is one of the oldest bulb crops, known to mankind and consumed worldwide. It is one of the most important commercial vegetable crops grown in Egypt and believed to be originated in Central Asia. It is valued for its distinct pungent flavor and is an essential ingredient for the cuisine of many regions. Onion is the queen of the kitchen (Selvaraj, 1976). The onion is preferred mainly because of its green leaves, immature and mature bulbs are either eaten raw or cooked as a vegetable (Kukanoor, 2005). Egypt is considered the $4^{\text {th }}$ producer of dry onion in the world, where it produce about 2,208,080 ton, average yield per hectare is 
$358833 \mathrm{~kg} \mathrm{ha}^{-1}$ and the total harvested area from dry onion 61535 ha in 2010 (FAO, 2012).

Seed viability is a matter of great concern and measures to maintain germination efficiency of stored seeds have significant economical implications. A range of pre-harvest, harvest and post-harvest conditions affect seed viability (Basu, 1995). On the other hand, seed ageing which is linked to loss of seed viability with time is inevitable and the best that can be done is to lower its rate (Coolbear, 1995). Many factors contribute to seed ageing. These include genetics, mechanical damage, relative humidity and temperature of the storage environment, seed water content, presence of microflora, seed maturity, etc. The rate of loss of seed viability is mainly a function of temperature and seed moisture content (McDonald, 2004). During ageing, seed viability and vigour decrease. Furthermore, the losses of viability and vigour in seeds differ with species and cultivars (Demirkaya et al. 2010).

Onion seeds in general have poor longevity and lose viability rapidly within 1-2 years (Yasseen, 1994). It is necessary to store seeds for a period of several months to a year or more. However, no storage procedure guarantees that seeds will remain viable forever. Seeds eventually lose vigor and then viability with time (Korkmaz et al. 2004). Controlled atmosphere (CA) storage is particularly effective when vegetables are held under refrigeration. Such a system is exceptionally valuable for preserving high market value produce such as cauliflower, asparagus and broccoli. Under controlled atmospheric conditions, the atmosphere is modified from that of the ambient atmosphere, and these conditions are maintained throughout the storage. MAP uses the same principles as CA storage; however, it is used on smaller quantities of produce and the atmosphere is only initially modified (Das, 2004).

Therefore, the aim of this study was to investigate the effect of foliar application with 12 commercial compounds on onion seed longevity and storage under controlled atmosphere. Two storage temperatures (room temperature and cold temperature or $5^{\circ} \mathrm{C}$ ) and changes in antioxidant enzymes activities of onion seeds during storage also were highlighted.

\section{Materials and Methods}

\section{Experimental design}

The aim of this investigation was to study the effect of foliar application with 12 commercial compounds and untreated treatment (foliar with water) on onion seed longevity under sandy soil and saline irrigation water $(\mathrm{EC}=$ $3.9 \mathrm{dS} \mathrm{m}^{-1}$ ) conditions. One commercial onion cultivar was selected for this study, viz., Giza 20. The seeds for this study produced at Waddy Elnatron farm, Agricultural Experimental Station of the Faculty of Agriculture, Cairo University. This study conducted in two successive seasons in 2008/2009 and
2009/2010. Waddy Elnatron farm is reclaimed sand soil, its chemical and physical characterization and the properties of these commercial compounds are mentioned in details in Shehata et al. (2013). The commercial compounds were treated three times during the season of growth at vegetative growth, flowering and flower set (after two months of sowing date, one month later and one month later, respectively). A completely randomize blocks design (CRBD) was used with four replicates.

\section{Biochemical assessments of onion seed}

Two grams of seeds were ground in a mortar and homogenized in $20 \mathrm{ml}$ of $0.1 \mathrm{M}$ phosphate puffer $(\mathrm{pH} 7.8)$ containing $0.4 \mathrm{~g}$ polyvinyl pyrrolidone, $2 \mathrm{mM}$ dithiotheitol and $0.1 \mathrm{mM}$ EDTA followed by centrifuging at $16,000 \times \mathrm{g}$ for $15 \mathrm{~min}$ at $4^{\circ} \mathrm{C}$ (Rao et al. 2006). Catalase (CAT), and peroxidase (POD) activity and malondialdehyde (MDA) content were determined according to Chance and Maehly (1955), Amako et al. (1994) and Health and Parker (1968), respectively. For more details about the enzyme activities as mentioned in Shehata et al. (2013).

\section{Storage of onion seed under controlled atmosphere}

This part of this experiment aimed to study the effect of different controlled atmospheres and exposure periods at two storage temperatures, i.e., room temperature and $5^{\circ} \mathrm{C}$ on seed germination, moisture content and change in antioxidant enzymes activity of onion seeds during storage period. The following parameters were measured after harvest and every 4 months: seed water content, seed germination, chemical analysis and biochemical assessment (CAT, and POD and MDA content).

\section{Preparation of onion seeds for exposure to different gas mixtures}

The experimental unit consisted of $75 \mathrm{~g}$ of onion seeds. Each unit was packaged in non perforated polypropylene bag. The bags were put inside vacuum packages equipment to make vacuum inside the bags and then injection of mixed gases. Seeds of this experiment were divided into two groups, half of them stored in room temperature and the other stored in cold temperature $\left(5^{\circ} \mathrm{C}\right)$.

\section{Gas mixture flow and exposure technique}

Gas mixture was released from a pressurized cylinder into the previous vacuumed packages. The experiment was replicated six times. The following four gas mixtures were used:

1- Gas mixture 1 (CA1): $4 \% \mathrm{CO}_{2}, 95.5 \% \mathrm{~N}_{2}$ and $0.5 \% \mathrm{O}_{2}$

2- Gas mixture 2 (CA2): $8 \% \mathrm{CO}_{2}, 91 \% \mathrm{~N}_{2}$ and $1 \% \mathrm{O}_{2}$

3- Gas mixture 3 (CA3): $16 \% \mathrm{CO}_{2}, 82 \% \mathrm{~N}_{2}$ and $2 \% \mathrm{O}_{2}$

4- Gas mixture 3 (CA4): $24 \% \mathrm{CO}_{2,} 73 \% \mathrm{~N}_{2}$ and $3 \% \mathrm{O}_{2}$ 
Table 1: Effect of storage temperature, controlled atmosphere and their interactions on germination (\%), water content (\%), catalase and peroxidase activity, and malondialdehyde content of onion seeds stored for 12 months

\begin{tabular}{|c|c|c|c|c|c|}
\hline \multirow[t]{2}{*}{ Storage temperature } & \multicolumn{5}{|c|}{ Controlled atmosphere } \\
\hline & CA1 & $\mathrm{CA} 2$ & CA3 & CA4 & Mean \\
\hline \multicolumn{6}{|l|}{ Germination (\%) } \\
\hline Room temperature & $87.4 \mathrm{a}$ & $88.7 \mathrm{a}$ & $85.7 \mathrm{~b}$ & $84.4 \mathrm{~b}-\mathrm{c}$ & $86.5 \mathrm{a}$ \\
\hline Cold temperature $\left(5^{\circ} \mathrm{C}\right)$ & $83.5 \mathrm{c}$ & $85.0 \mathrm{~b}$ & $81.8 \mathrm{~d}$ & $79.9 \mathrm{e}$ & $82.5 \mathrm{~b}$ \\
\hline \multicolumn{6}{|l|}{ Water content $(\%)$} \\
\hline Room temperature & $4.25 \mathrm{c}$ & $4.13 \mathrm{~d}$ & $4.25 \mathrm{c}$ & $4.25 \mathrm{~cd}$ & $4.22 \mathrm{~b}$ \\
\hline Cold temperature $\left(5^{\circ} \mathrm{C}\right)$ & $4.71 \mathrm{~b}$ & $4.68 \mathrm{~b}$ & $4.86 \mathrm{a}$ & $4.84 \mathrm{a}$ & $4.77 \mathrm{a}$ \\
\hline \multicolumn{6}{|c|}{ Catalase activity $\left(\mu \mathrm{mol} \mathrm{H}_{2} \mathrm{O}_{2}\right.$ consumed $/ \mathrm{mg}$ protein $\left./ \mathrm{min}\right)$} \\
\hline Room temperature & $16.8 \mathrm{a}$ & $16.8 \mathrm{a}$ & $17.0 \mathrm{a}$ & $17.4 \mathrm{a}$ & $17.0 \mathrm{a}$ \\
\hline Cold temperature $\left(5^{\circ} \mathrm{C}\right)$ & $14.7 \mathrm{c}$ & $15.0 \mathrm{~b}-\mathrm{c}$ & $14.7 \mathrm{c}$ & $15.6 \mathrm{a}-\mathrm{c}$ & $15.0 \mathrm{~b}$ \\
\hline \multicolumn{6}{|l|}{ Peroxidase activity (Enzyme unit*) } \\
\hline Room temperature & $14.8 \mathrm{a}$ & $14.4 \mathrm{a}$ & $12.1 \mathrm{~b}$ & $9.95 \mathrm{c}$ & $12.8 \mathrm{a}$ \\
\hline Cold temperature $\left(5^{\circ} \mathrm{C}\right)$ & $8.76 \mathrm{c}-\mathrm{d}$ & $9.02 \mathrm{c}$ & $8.85 \mathrm{c}-\mathrm{d}$ & $7.37 \mathrm{~d}$ & $8.50 \mathrm{~b}$ \\
\hline \multicolumn{6}{|c|}{ Malondialdehyde content $\left(\mathrm{mmol} \mathrm{g}^{-1} \mathrm{fw}\right)$} \\
\hline Room temperature & $11.09 \mathrm{c}$ & $10.53 \mathrm{c}$ & $12.72 \mathrm{~b}$ & $13.93 \mathrm{~b}$ & $12.07 \mathrm{~b}$ \\
\hline Cold temperature $\left(5^{\circ} \mathrm{C}\right)$ & $13.48 \mathrm{~b}$ & $12.55 \mathrm{~b}$ & $17.18 \mathrm{a}$ & $18.11 \mathrm{a}$ & $15.33 \mathrm{a}$ \\
\hline
\end{tabular}

CA1: $4 \% \mathrm{CO}_{2,} 95.5 \% \mathrm{~N}_{2}$ and $0.5 \% \mathrm{O}_{2}$

CA3: $16 \% \mathrm{CO}_{2} 82 \% \mathrm{~N}_{2}$ and $2 \% \mathrm{O}_{2}$

CA2: $8 \% \mathrm{CO}_{2,} 91 \% \mathrm{~N}_{2}$ and $1 \% \mathrm{O}_{2}$

CA4: $24 \% \mathrm{CO}_{2} 73 \% \mathrm{~N}_{2}$ and $3 \% \mathrm{O}$

* Enzyme unit (EU) is defined as the amount of enzyme required to cause an increase in the optical density (OD) at $430 \mathrm{~nm} / \mathrm{min}$ at $25^{\circ} \mathrm{C}$ under standard conditions $(0.01 \mathrm{OD}=1 \mathrm{EU})$.

\section{Exposure periods}

All seed treatments at each gas mixture were exposed for $3,6,9,12,15,30,60,120$ or 240 day.

\section{Statistical analysis}

Data were organized in a completely randomized block design (CRBD). Analyses of variance (ANOVA) were obtained using M. State statistical software. The new LSD method (Waller and Duncan, 1969) was used for testing the significance of means in all experiments conducted.

\section{Results}

\section{Effects on onion seed quality}

This part of the investigation aimed to study the effect of different controlled atmospheres, CA1 $\left(4 \% \mathrm{CO}_{2}, 95.5 \% \mathrm{~N}_{2}\right.$ and $\left.0.5 \% \mathrm{O}_{2}\right), \mathrm{CA} 2\left(8 \% \mathrm{CO}_{2}, 91 \% \mathrm{~N}_{2}\right.$ and $\left.1 \% \mathrm{O}_{2}\right), \mathrm{CA} 3(16 \%$ $\mathrm{CO}_{2}, 82 \% \mathrm{~N}_{2}$ and $\left.2 \% \mathrm{O}_{2}\right)$ and $\mathrm{CA} 4\left(24 \% \mathrm{CO}_{2}, 73 \% \mathrm{~N}_{2}\right.$ and $\left.3 \% \mathrm{O}_{2}\right)$, ten exposure periods $(0,3,6,12,15,30,60,120$ and 240 days) and two storage temperatures (room temperature and cold temperature or $5^{\circ} \mathrm{C}$ ) on seeds germination, moisture content and changes in antioxidant enzymes activities of onion seeds during storage.

\section{Germination percent}

\section{Effect of storage temperature on germination percent}

The germination percentage of onion seeds at different controlled atmospheres and storage temperatures are presented in Table 1. Statistical analysis shows that there were significant differences of storage temperature on germination percentage (Fig. 1). The germination percentage was 86.57 at room temperature and 82.56 at cold temperature $\left(5^{\circ} \mathrm{C}\right)$.

\section{Effect of controlled atmospheres on germination percent}

The means of germination percentages were 85.50, $86.85,83.75$ and 82.15 for CA1, CA2, CA3 and CA4, respectively as shown in Fig. 2. The highest mean germination percent (86.85) was noticed for CA2. These results may be due to containing this controlled atmosphere (CA2) the highest catalase and peroxidase activities and the lowest malondialdehyde content than all other controlled atmospheres. These results agree with those of Demirkaya et al. (2010) who reported a high level of correlation between the loss of seed viability and the decreases that occurred in CAT and SOD activities in the seeds.

\section{Effect of exposure period on germination percent}

There was a significant difference between exposure periods on germination percent. The highest germination percent (91.33) was recorded with 120 days exposure period. These results may be due to high catalase and peroxidase activities in this exposure period than all other exposure periods. Regarding the effect of interaction between exposure periods and controlled atmospheres, data in Fig. 2 show that percent of germination in different controlled atmospheres increased with the increasing of exposure periods until 120 days and then decreased. The highest germination percent (94.33) was recorded for CA2 after 120 days exposure 

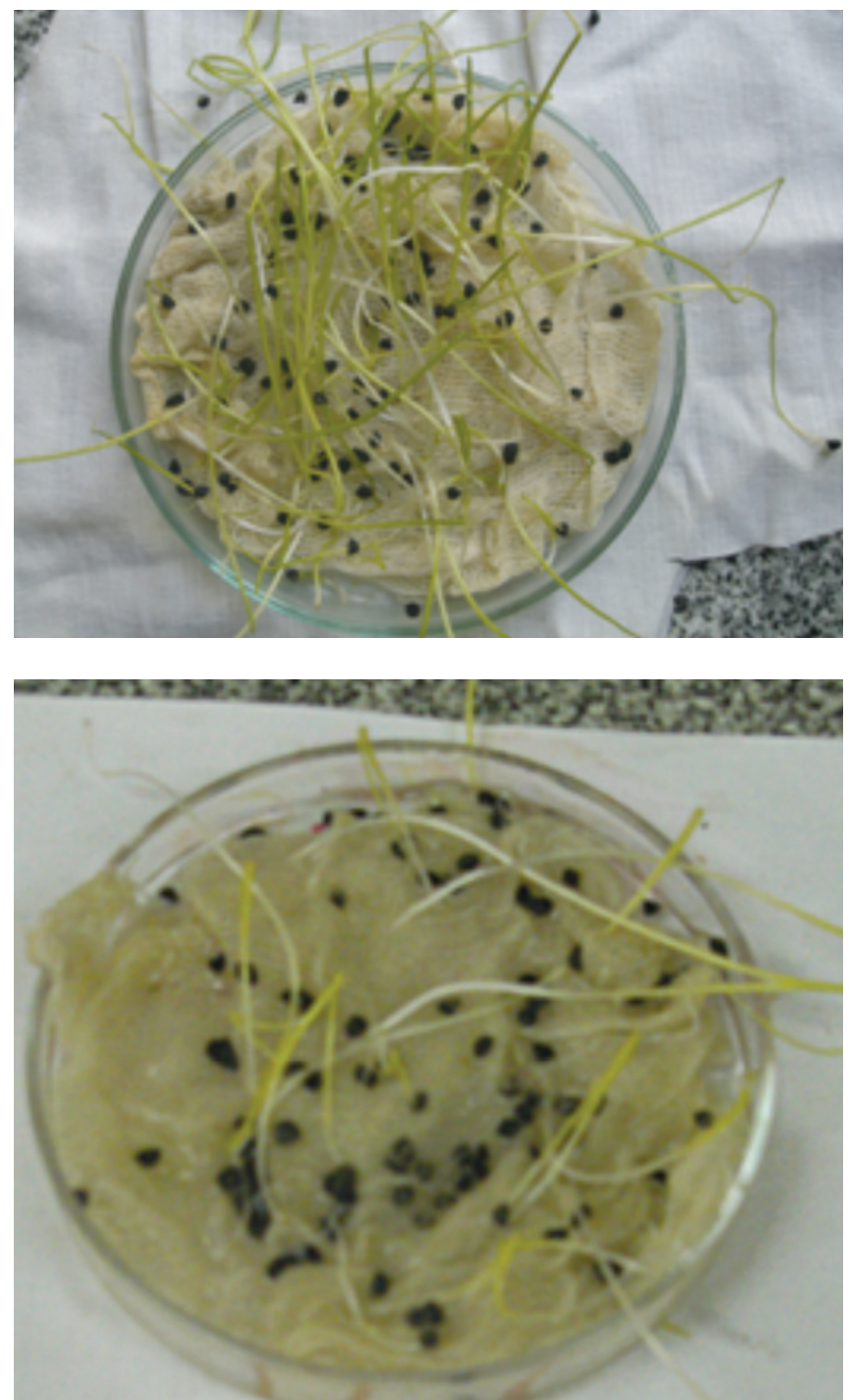

Fig. 1: Effect of controlled atmosphere $\left(8 \% \mathrm{CO}_{2} 91 \% \mathrm{~N}_{2}\right.$ and $\left.1 \% \mathrm{O}_{2}\right)$ on germination percentage of onion seeds (lift, seeds treated with controlled atmosphere and right is untreated seeds or control, photo by K. Abd ElGawad)

period. It could be concluded that onion seeds treated with CA2 and exposed for 120 days exposure periods maintain the germination percentage after 12 months of storage at room temperature.

\section{Moisture or water content}

\section{Effect of storage temperature on moisture content}

Storage temperature and water content are the most important factors affecting seed longevity, with seed water content usually being more influential than temperature. As shown in Table 1, data indicate that water content of onion seeds was significantly increased with decreasing storage temperature in all controlled atmospheres. The water content was 4.22 at room temperature and 4.77 at 5
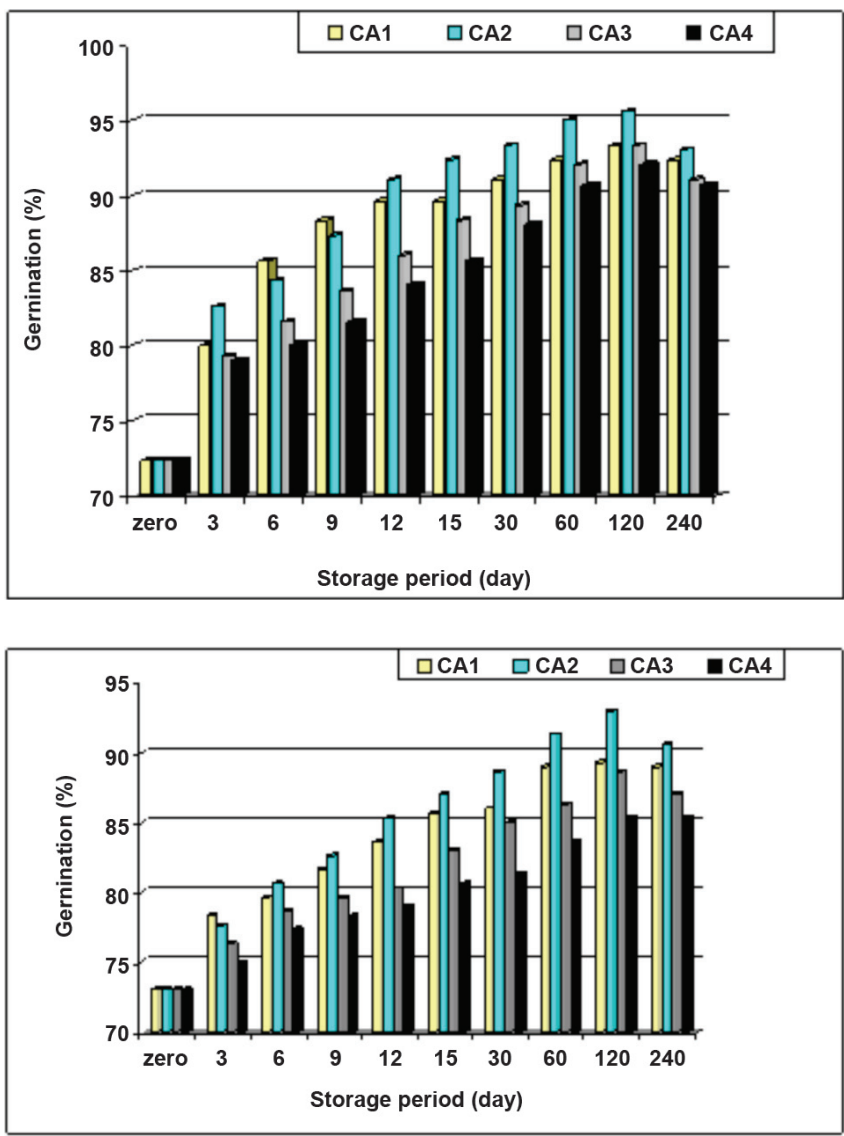

Fig. 2: Effect of the interaction between storage temperature (A, room temperature and $\mathrm{B}, 5^{\circ} \mathrm{C}$ or cold temperature), controlled atmosphere and exposure period on germination percent of onion seeds stored for 12 months. For more details about CA1 to CA4:

CA1: $4 \% \mathrm{CO}_{2}, 95.5 \% \mathrm{~N}_{2}$ and $0.5 \% \mathrm{O}_{2}$

CA2: $8 \% \mathrm{CO}_{2} 91 \% \mathrm{~N}_{2}$ and $1 \% \mathrm{O}_{2}$

CA3: $16 \% \mathrm{CO}_{2}, 82 \% \mathrm{~N}_{2}$ and $2 \% \mathrm{O}_{2}$

CA4: $24 \% \mathrm{CO}_{2}, 73 \% \mathrm{~N}_{2}$ and $3 \% \mathrm{O}_{2}$

C. These results may be due to a rise in air moisture content in cold storage.

Muhammad and Anjum (2002) reported that water content is the most important factor involved in the deterioration of seeds. The majority of seeds come into equilibrium between their internal water content and the relative humidity of the atmosphere in which they are stored. The life of the seed is halved for each $1 \%$ increase in water content of the seeds. Data presented in Table 1 show that water content significantly increased with decreasing storage period in all controlled atmospheres. The highest water content (4.86) was recorded for $\mathrm{CA} 3$ at $5{ }^{\circ} \mathrm{C}$.

\section{Effect of controlled atmosphere on moisture content}

Statistical analysis shows that there was a significant difference between controlled atmospheres on water content. Water content was $4.485,4.408,4.558$ and 4.545 for CA1, CA2, CA3 and CA4, respectively. Data in Table 1 show that $\mathrm{CA} 2 \mathrm{had}$ the least water content (4.13). 
Table 2: Effect of exposure period and different controlled atmosphere on water content of onion seeds stored for 12 months

\begin{tabular}{|c|c|c|c|c|c|}
\hline \multirow{2}{*}{$\begin{array}{c}\text { Exposure periods } \\
\text { (days) }\end{array}$} & \multicolumn{5}{|c|}{ Controlled atmospheres } \\
\cline { 2 - 6 } & CA1 & CA2 & CA3 & CA4 & Mean \\
\hline zero & $4.95 \mathrm{a}$ & $4.95 \mathrm{a}$ & $4.95 \mathrm{a}$ & $4.95 \mathrm{a}$ & $4.95 \mathrm{a}$ \\
\hline $\mathbf{3}$ & $4.68 \mathrm{c}-\mathrm{e}$ & $4.63 \mathrm{~d}-\mathrm{f}$ & $4.75 \mathrm{~b}-\mathrm{c}$ & $4.71 \mathrm{~b}$ \\
\hline $\mathbf{6}$ & $4.61 \mathrm{e}-\mathrm{g}$ & $4.53 \mathrm{~h}$ & $4.70 \mathrm{c}-\mathrm{d}$ & $4.70 \mathrm{c}-\mathrm{d}$ & $4.63 \mathrm{c}$ \\
\hline $\mathbf{9}$ & $4.51 \mathrm{~h}-\mathrm{i}$ & $4.50 \mathrm{~h}-\mathrm{j}$ & $4.66 \mathrm{~d}-\mathrm{e}$ & $4.63 \mathrm{~d}-\mathrm{f}$ & $4.57 \mathrm{~d}$ \\
\hline $\mathbf{1 2}$ & $4.56 \mathrm{f}-\mathrm{h}$ & $4.45 \mathrm{i}-\mathrm{k}$ & $4.53 \mathrm{~h}$ & $4.55 \mathrm{~g}-\mathrm{h}$ & $4.52 \mathrm{~d}$ \\
\hline $\mathbf{1 5}$ & $4.43 \mathrm{j}-1$ & $4.36 \mathrm{l}-\mathrm{o}$ & $4.51 \mathrm{~h}-\mathrm{i}$ & $4.45 \mathrm{i}-\mathrm{k}$ & $4.44 \mathrm{e}$ \\
\hline $\mathbf{3 0}$ & $4.40 \mathrm{k}-\mathrm{n}$ & $4.35 \mathrm{~m}-\mathrm{p}$ & $4.41 \mathrm{k}-\mathrm{m}$ & $4.4 \mathrm{k}-\mathrm{m}$ & $4.39 \mathrm{e}$ \\
\hline $\mathbf{6 0}$ & $4.28 \mathrm{p}-\mathrm{q}$ & $4.11 \mathrm{~s}-\mathrm{t}$ & $4.38 \mathrm{k}-\mathrm{n}$ & $4.33 \mathrm{n}-\mathrm{p}$ & $4.27 \mathrm{f}$ \\
\hline $\mathbf{1 2 0}$ & $4.21 \mathrm{q}-\mathrm{r}$ & $4.10 \mathrm{t}$ & $4.33 \mathrm{n}-\mathrm{p}$ & $4.30 \mathrm{o}-\mathrm{p}$ & $4.23 \mathrm{f}$ \\
\hline $\mathbf{2 4 0}$ & $4.18 \mathrm{r}-\mathrm{s}$ & $4.08 \mathrm{t}$ & $4.33 \mathrm{n}-\mathrm{p}$ & $4.33 \mathrm{n}-\mathrm{p}$ & $4.23 \mathrm{f}$ \\
\hline
\end{tabular}

CA1: $4 \% \mathrm{CO}_{2} 95.5 \% \mathrm{~N}_{2}$ and $0.5 \% \mathrm{O}_{2}$ CA3: $16 \% \mathrm{CO}_{2}, 82 \% \mathrm{~N}_{2}$ and $2 \% \mathrm{O}_{2}$

\section{Effect of exposure period on moisture content}

Data illustrated in Table 2 shows that water content was affected by exposure periods. There were significant decreases in water content with increasing exposure periods. Data indicate that the untreated seeds had the highest water content (4.95). The least water content was recorded for the exposure period of 120 and 240 days. These results are in
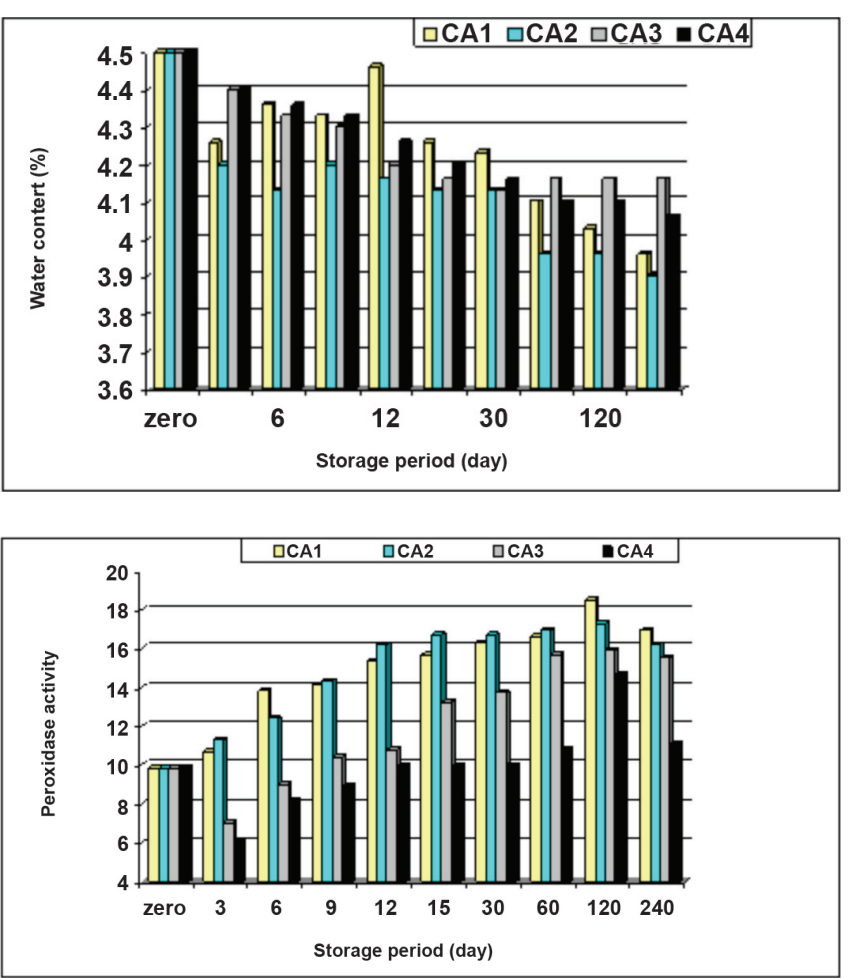

Figure 3: Effect of the interaction between storage temperature (A, room temperature and $\mathrm{B}$, cold temperature), controlled atmosphere and exposure period on water content of onion seeds stored for 12 months. For more details about CA1 to CA4:

CA1: $4 \% \mathrm{CO}_{2} 95.5 \% \mathrm{~N}_{2}$ and $0.5 \% \mathrm{O}_{2}$

CA2: $8 \% \mathrm{CO}_{2}, 91 \% \mathrm{~N}_{2}$ and $1 \% \mathrm{O}_{2}$

CA3: $16 \% \mathrm{CO}_{2}, 82 \% \mathrm{~N}_{2}$ and $2 \% \mathrm{O}_{2}$

CA4: $24 \% \mathrm{CO}_{2}, 73 \% \mathrm{~N}_{2}$ and $3 \% \mathrm{O}_{2}$ agreement with those of Shehata et al. (2009). It appears from data in Fig. 3 the lowest water content (3.90) was recorded for CA2 exposed for 240 days at room temperature. On the other hand, the highest water content (5.40) was recorded for zero day exposure periods at $5^{\circ} \mathrm{C}$.

\section{Effects on biochemical assessment in onion seed Effects on catalase activity}

\section{Effect of storage temperature on catalase activity}

There was a significant effect of storage temperature on catalase activity. It appears that catalase activity was decreased with the decreasing of storage temperature. Data in Table 1 show that catalase activity was 17.4 at room temperature and 15.03 at $5^{\circ} \mathrm{C}$. Concerning the effect of the interaction between storage temperature and controlled atmosphere, data in Table 3 indicate that there was a significant effect of the interaction on catalase activity. The highest catalase activity was recorded for CA1, CA2, CA3 and CA4 at room temperature.

\section{Effect of controlled atmosphere on catalase activity}

Concerning to the effect of the controlled atmosphere on catalase activity, data in Table $\mathbf{1}$ show that there was non significant difference of controlled atmosphere on catalase activity. These results agree with those obtained by Pablo et al. (2007) who reported non significant differences in antioxidant enzyme stored in air or in controlled atmosphere.

\section{Effect of exposure period on catalase activity}

Regarding the effect of exposure period on catalase activity, data in Table 3 show that the exposure for 120 and 60 days recorded the highest catalase activity (18.0 and 17.9). Catalase activity increased with increasing the exposure period until 120 days and then decreased. With respect to 
Table 3: Effect of exposure period and different controlled atmospheres on catalase activity of onion seeds stored for 12 months

\begin{tabular}{|c|c|c|c|c|c|}
\hline \multirow{2}{*}{$\begin{array}{l}\text { Exposure period } \\
\text { day) }\end{array}$} & \multicolumn{5}{|c|}{ Controlled atmospheres } \\
\cline { 2 - 6 } & $\mathbf{C A 1}$ & $\mathbf{C A 2}$ & $\mathbf{C A 3}$ & CA4 & Mean \\
\hline zero & $11.8 \mathrm{j}$ & $11.8 \mathrm{j}$ & $11.8 \mathrm{j}$ & $11.8 \mathrm{j}$ & $11.8 \mathrm{e}$ \\
\hline $\mathbf{3}$ & $14.7 \mathrm{~g}-\mathrm{j}$ & $15.8 \mathrm{~b}-\mathrm{i}$ & $14.3 \mathrm{~g}-\mathrm{j}$ & $14.1 \mathrm{~g}-\mathrm{j}$ & $14.7 \mathrm{c}-\mathrm{d}$ \\
\hline $\mathbf{6}$ & $16.0 \mathrm{~b}-\mathrm{i}$ & $16.3 \mathrm{a}-\mathrm{i}$ & $14.4 \mathrm{~g}-\mathrm{j}$ & $14.8 \mathrm{e}-\mathrm{j}$ & $15.3 \mathrm{c}-\mathrm{d}$ \\
\hline $\mathbf{9}$ & $15.2 \mathrm{c}-\mathrm{i}$ & $16.9 \mathrm{a}-\mathrm{h}$ & $14.9 \mathrm{e}-\mathrm{j}$ & $15.5 \mathrm{~b}-\mathrm{j}$ & $15.7 \mathrm{a}-\mathrm{c}$ \\
\hline $\mathbf{1 2}$ & $15.7 \mathrm{~b}-\mathrm{i}$ & $16.7 \mathrm{a}-\mathrm{i}$ & $16.0 \mathrm{a}-\mathrm{i}$ & $16.7 \mathrm{a}-\mathrm{j}$ & $16.2 \mathrm{~b}-\mathrm{c}$ \\
\hline $\mathbf{1 5}$ & $16.9 \mathrm{a}-\mathrm{i}$ & $17.2 \mathrm{a}-\mathrm{g}$ & $16.8 \mathrm{a}-\mathrm{i}$ & $16.9 \mathrm{a}-\mathrm{j}$ & $16.9 \mathrm{~b}-\mathrm{c}$ \\
\hline $\mathbf{3 0}$ & $17.3 \mathrm{a}-\mathrm{i}$ & $18.1 \mathrm{a}-\mathrm{e}$ & $17.3 \mathrm{a}-\mathrm{g}$ & $16.1 \mathrm{a}-\mathrm{i}$ & $17.2 \mathrm{a}-\mathrm{b}$ \\
\hline $\mathbf{6 0}$ & $18.1 \mathrm{a}-\mathrm{g}$ & $18.5 \mathrm{a}-\mathrm{b}$ & $17.5 \mathrm{a}-\mathrm{g}$ & $17.4 \mathrm{a}-\mathrm{g}$ & $17.8 \mathrm{a}$ \\
\hline $\mathbf{1 2 0}$ & $18.5 \mathrm{a}-\mathrm{d}$ & $18.8 \mathrm{a}-\mathrm{b}$ & $18.1 \mathrm{a}-\mathrm{c}$ & $17.7 \mathrm{a}-\mathrm{f}$ & $18.2 \mathrm{a}$ \\
\hline $\mathbf{2 4 0}$ & $13.5 \mathrm{i}-\mathrm{j}$ & $15.8 \mathrm{~b}-\mathrm{i}$ & $14.2 \mathrm{~g}-\mathrm{j}$ & $14.6 \mathrm{e}-\mathrm{j}$ & $14.5 \mathrm{~b}$ \\
\hline
\end{tabular}

CA1: $4 \% \mathrm{CO}_{2} 95.5 \% \mathrm{~N}_{2}$ and $0.5 \% \mathrm{O}_{2}$

CA2: $8 \% \mathrm{CO}_{2} 91 \% \mathrm{~N}_{2}$ and $1 \% \mathrm{O}$

CA3: $16 \% \mathrm{CO}_{2,} 82 \% \mathrm{~N}_{2}$ and $2 \% \mathrm{O}_{2} \quad \mathrm{CA} 4: 24 \% \mathrm{CO}_{2,}, 73 \% \mathrm{~N}_{2}$ and $3 \% \mathrm{O}_{2}$
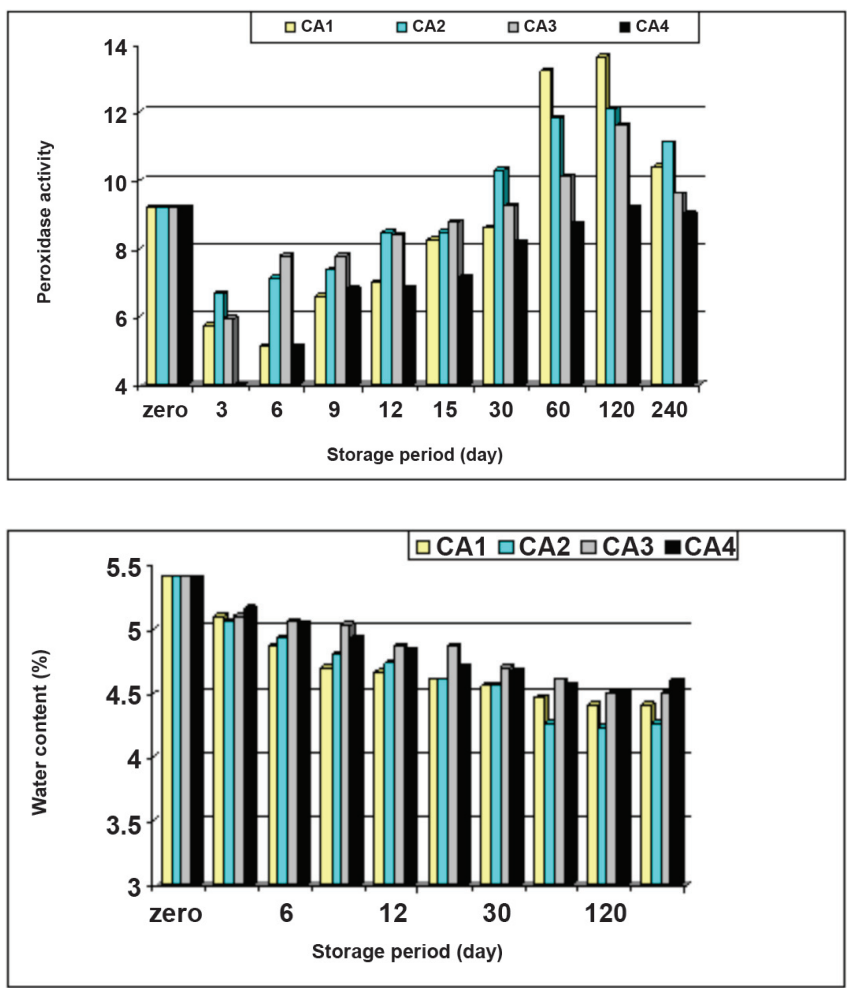

Fig. 4: Effect of the interaction between storage temperature (A, room temperature and $\mathrm{B}$, cold temperature), controlled atmosphere and exposure period on catalase activity of onion seeds stored for 12 months. For more details about CA1 to CA4:

CA1: $4 \% \mathrm{CO}_{2} .95 .5 \% \mathrm{~N}_{2}$ and $0.5 \% \mathrm{O}_{2}$

$\mathrm{CA} 2: 8 \% \mathrm{CO}_{2} 91 \% \mathrm{~N}_{2}$ and $1 \% \mathrm{O}_{2}$

CA3: $16 \% \mathrm{CO}_{2} 82 \% \mathrm{~N}_{2}$ and $2 \% \mathrm{O}_{2}$

CA4: $24 \% \mathrm{CO}_{2}, 73 \% \mathrm{~N}_{2}$ and $3 \% \mathrm{O}_{2}$

the effect of the interaction between the exposure period and controlled atmosphere, data in Table 3 show that the highest catalase activity was recorded for CA2 exposed for 60 and 120 days. With respect to the effect of the interaction between storage temperature and exposure period on catalase activity, data show that at different exposure periods, the room temperature had the highest catalase activity. The highest catalase activity was recorded for 60 and 120 days exposure periods at room temperature.
It appears from data in Fig. $\mathbf{4}$ that the interaction between storage temperature, controlled atmosphere and exposure period had a significant effect on catalase activity. The exposure period for 30, 60 or 120 days had the highest catalase activity with CA1 and CA2 at room temperature, and 60 and 120 days exposure period for all different controlled atmospheres at both temperatures. The highest catalase activity was recorded for $\mathrm{CA} 2$ exposed for 120 days at room temperature.

\section{Effects on peroxidase activity}

\section{Effect of storage temperature on peroxidase activity}

Data in Table 1 show that peroxidase activity increased as storage temperature increased. The peroxidase activity was 12.8 at room temperature and 8.5 at $5^{\circ} \mathrm{C}$. These results may be due to that the effect of controlled atmosphere increased by increasing the exposure period and increasing the temperature of treatment. These results disagree with those of Demirkaya et al. (2010) as they reported as storage temperature increased the peroxidase activity decreased. As regard to the effect of the interaction between the storage temperature and controlled atmosphere on peroxidase activity, data in Table 1 indicate that peroxidase activity at different controlled atmospheres is higher at room temperature than at $5^{\circ} \mathrm{C}$. The highest value of peroxidase (14.4) was recorded for $\mathrm{CA} 2$ at room temperature.

\section{Effect of controlled atmosphere on peroxidase activity}

Concerning the effect of the controlled atmosphere on peroxidase activity, data in Table $\mathbf{4}$ shows that the CA1 and CA2 had the highest values of peroxidase (11.79 and 11.72 , respectively) compared with all other controlled atmospheres. These results agree with those obtained by Christian et al. (2001). These results may be due to containing these controlled atmospheres the lowest water and malondialdehyde content. 
Table 4: Effect of exposure period and different controlled atmospheres on peroxidase activity of onion seeds stored for 12 months

\begin{tabular}{|c|c|c|c|c|c|}
\hline \multirow{2}{*}{$\begin{array}{l}\text { Exposure periods } \\
\text { (days) }\end{array}$} & \multicolumn{5}{|c|}{ Controlled atmospheres } \\
\hline & CA1 & CA2 & CA3 & CA4 & Mean \\
\hline zero & $9.53 \mathrm{~g}-\mathrm{k}$ & $9.53 \mathrm{~g}-\mathrm{k}$ & $9.53 \mathrm{~g}-\mathrm{k}$ & $9.53 \mathrm{~g}-\mathrm{k}$ & $9.53 \mathrm{c}-\mathrm{d}$ \\
\hline 3 & 9.78 e-j & $9.88 \mathrm{e}-\mathrm{j}$ & $7.46 \mathrm{j}-\mathrm{k}$ & $7.54 \mathrm{j}-\mathrm{k}$ & $8.66 \mathrm{~d}-\mathrm{e}$ \\
\hline 6 & $10.2 \mathrm{e}-\mathrm{j}$ & $9.89 e-j$ & $7.41 \mathrm{j}-\mathrm{k}$ & $7.30 \mathrm{j}-\mathrm{k}$ & $8.70 \mathrm{~d}-\mathrm{e}$ \\
\hline 9 & $11.1 \mathrm{~d}-\mathrm{i}$ & $9.66 \mathrm{e}-\mathrm{j}$ & $11.2 \mathrm{~d}-\mathrm{i}$ & $7.51 \mathrm{j}-\mathrm{k}$ & $9.86 \mathrm{c}-\mathrm{d}$ \\
\hline 12 & $11.1 \mathrm{~d}-\mathrm{i}$ & $11.7 \mathrm{c}-\mathrm{h}$ & $12.5 \mathrm{~b}-\mathrm{f}$ & $8.48 \mathrm{i}-\mathrm{k}$ & $10.9 \mathrm{~b}-\mathrm{c}$ \\
\hline 15 & $11.6 \mathrm{c}-\mathrm{h}$ & $12.7 \mathrm{~b}-\mathrm{e}$ & $11.6 \mathrm{c}-\mathrm{h}$ & $8.80 \mathrm{~h}-\mathrm{k}$ & $11.1 \mathrm{~b}-\mathrm{c}$ \\
\hline 30 & $11.5 \mathrm{c}-\mathrm{h}$ & $12.9 \mathrm{~b}-\mathrm{e}$ & $10.3 \mathrm{e}-\mathrm{j}$ & $11.8 \mathrm{~b}-\mathrm{g}$ & $11.5 \mathrm{a}-\mathrm{b}$ \\
\hline 60 & $12.7 \mathrm{~b}-\mathrm{e}$ & 13.8 a-d & $11.2 \mathrm{~d}-\mathrm{i}$ & $9.97 \mathrm{e}-\mathrm{j}$ & $11.9 \mathrm{a}-\mathrm{b}$ \\
\hline 120 & $14.8 \mathrm{a}-\mathrm{b}$ & $14.8 \mathrm{a}-\mathrm{b}$ & $12.6 \mathrm{~b}-\mathrm{e}$ & 9.04 g-k & $12.8 \mathrm{a}$ \\
\hline 240 & $12.8 \mathrm{~b}-\mathrm{e}$ & $12.7 \mathrm{~b}-\mathrm{e}$ & $10.8 \mathrm{~d}-\mathrm{i}$ & $6.59 \mathrm{k}$ & $11.0 \mathrm{~b}-\mathrm{c}$ \\
\hline
\end{tabular}

CA1: $4 \% \mathrm{CO}_{2} 95.5 \% \mathrm{~N}_{2}$ and $0.5 \% \mathrm{O}_{2}$

$\mathrm{CA} 3: 16 \% \mathrm{CO}_{2}, 82 \% \mathrm{~N}_{2}$ and $2 \% \mathrm{O}_{2}$

\section{Effect of exposure period on peroxidase activity}

As shown in Fig. 5, peroxidase activity increased as exposure period increased until 120 days and then decreased again. The highest peroxidase value (12.8) was recorded for 120 days exposure periods. With respect to the interaction between exposure period and controlled atmosphere on peroxidase activity, data in Table 4 show that peroxidase activity in different controlled atmospheres increased as exposure period increased and it reached the maximum value at 120 days and then decreased. The highest value of peroxidase was recorded at CA1 and CA2 exposed for 120 days. Concerning the effect of the interaction between storage temperature and exposure period on peroxidase activity, data in Table 4 show that peroxidase activity in all tested exposure periods increased as storage temperature increased. The highest peroxidase activity (14.7) was recorded for 120 days exposure period at room temperature.

\section{Effects on malondialdehyde content}

\section{Effect of storage temperature on malondialdehyde content}

Malondialdehyde content is often used as an indicator of lipid peroxidation. Data presented in Table 1 show that cold storage temperature $\left(5^{\circ} \mathrm{C}\right)$ showed the highest malondialdehyde content followed by room temperature. These results disagree with those obtained by Demirkaya et al. (2010). They found that as storage temperature increased the malondialdehyde content increased and antioxidant activity decreased. These results may be due to increasing the moisture content and decreasing the catalase and peroxidase at cold storage temperature than at room storage temperature. Concerning the effect of the interaction between storage temperatures and controlled atmosphere, data in Table 1 show that malondialdehyde content increased in all controlled atmospheres as storage temperature decreased. The lowest malondialdehyde content (10.5) was recorded for CA2 at room temperature
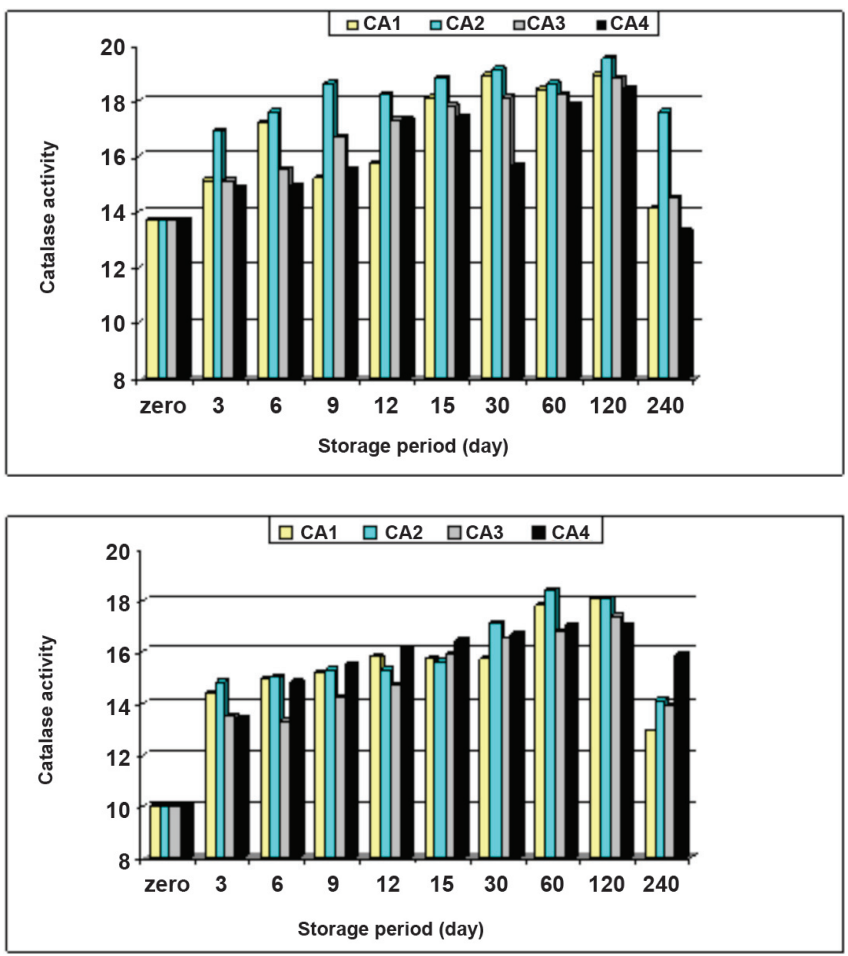

Fig. 5: Effect of the interaction between storage temperature (A, room temperature and B, cold temperature), controlled atmosphere and exposure period on peroxidase activity of onion seeds stored for 12 months. For more details about $\mathrm{CA} 1$ to $\mathrm{CA} 4$ :

CA1: $4 \% \mathrm{CO}_{2} 95.5 \% \mathrm{~N}_{2}$ and $0.5 \% \mathrm{O}_{2}$

CA2: $8 \% \mathrm{CO}_{2} 91 \% \mathrm{~N}_{2}$ and $1 \% \mathrm{O}_{2}$

CA3: $16 \% \mathrm{CO}_{2} 82 \% \mathrm{~N}_{2}$ and $2 \% \mathrm{O}_{2}$

CA4: $24 \% \mathrm{CO}_{2}, 73 \% \mathrm{~N}_{2}$ and $3 \% \mathrm{O}_{2}$

\section{Effect of controlled atmosphere on malondialdehyde content}

It appears from data in Table 5 that the CA2 show the lowest malondialdehyde content compared with all other controlled atmospheres. These results may be due to decreasing the moisture content and increasing the catalase and peroxidase in this atmosphere compared with all other controlled atmospheres. 
Table 5: Effect of exposure periods and different controlled atmospheres on malondialdehyde content of onion seeds stored for 12 months

\begin{tabular}{|c|c|c|c|c|c|}
\hline \multirow{2}{*}{$\begin{array}{l}\text { Exposure period } \\
\text { (days) }\end{array}$} & \multicolumn{4}{|c|}{ Controlled atmosphere } & \multirow{2}{*}{ Mean } \\
\cline { 2 - 5 } & CA1 & CA2 & CA3 & $24.75 \mathrm{a}$ & $24.75 \mathrm{a}$ \\
\hline zero & $24.75 \mathrm{a}$ & $24.75 \mathrm{a}$ & $24.75 \mathrm{a}$ & $22.42 \mathrm{a}-\mathrm{b}$ & $17.49 \mathrm{~b}$ \\
\hline $\mathbf{3}$ & $14.00 \mathrm{e}-\mathrm{i}$ & $13.49 \mathrm{f}-\mathrm{j}$ & $20.05 \mathrm{~b}-\mathrm{c}$ & $20.38 \mathrm{~b}-\mathrm{c}$ & $15.78 \mathrm{c}$ \\
\hline $\mathbf{9}$ & $12.61 \mathrm{~g}-\mathrm{m}$ & $11.99 \mathrm{~h}-\mathrm{o}$ & $18.16 \mathrm{c}-\mathrm{d}$ & $16.90 \mathrm{~d}-\mathrm{e}$ & $13.76 \mathrm{~d}$ \\
\hline $\mathbf{1 2}$ & $12.24 \mathrm{~h}-\mathrm{n}$ & $10.54 \mathrm{j}-\mathrm{q}$ & $15.35 \mathrm{~d}-\mathrm{g}$ & $15.73 \mathrm{~d}-\mathrm{f}$ & $13.00 \mathrm{de}$ \\
\hline $\mathbf{1 5}$ & $11.78 \mathrm{~h}-\mathrm{o}$ & $9.97 \mathrm{~m}-\mathrm{q}$ & $14.52 \mathrm{e}-\mathrm{h}$ & $14.08 \mathrm{e}-\mathrm{i}$ & $11.95 \mathrm{ef}$ \\
\hline $\mathbf{3 0}$ & $10.26 \mathrm{l}-\mathrm{q}$ & $10.23 \mathrm{l}-\mathrm{q}$ & $13.23 \mathrm{f}-\mathrm{k}$ & $13.02 \mathrm{f}-1$ & $11.02 \mathrm{fg}$ \\
\hline $\mathbf{6 0}$ & $9.68 \mathrm{~m}-\mathrm{q}$ & $9.17 \mathrm{o}-\mathrm{q}$ & $12.22 \mathrm{~h}-\mathrm{n}$ & $11.88 \mathrm{~h}-\mathrm{o}$ & $10.36 \mathrm{gh}$ \\
\hline $\mathbf{1 2 0}$ & $9.48 \mathrm{n}-\mathrm{q}$ & $8.57 \mathrm{p}-\mathrm{q}$ & $11.50 \mathrm{i}-\mathrm{p}$ & $10.28 \mathrm{k}-\mathrm{q}$ & $9.25 \mathrm{~h}$ \\
\hline $\mathbf{2 4 0}$ & $8.65 \mathrm{p}-\mathrm{q}$ & $7.95 \mathrm{q}$ & $10.13 \mathrm{l}-\mathrm{q}$ & $9.74 \mathrm{j}-\mathrm{q}$ & $9.62 \mathrm{gh}$ \\
\hline
\end{tabular}

CA1: $4 \% \mathrm{CO}_{2} 95.5 \% \mathrm{~N}_{2}$ and $0.5 \% \mathrm{O}$

CA3: $16 \% \mathrm{CO}_{2}, 82 \% \mathrm{~N}_{2}$ and $2 \% \mathrm{O}_{2}$

\section{Effect of exposure period on malondialdehyde content}

Regarding the effect of the exposure period on malondialdehyde content, data in Table 5 indicate that 120 days exposure period had the lowest malondialdehyde content.

Concerning the effect of interaction between exposure period and controlled atmosphere on malondialdehyde content, data in Table 5 indicate that malondialdehyde content decreased in all controlled atmospheres by increasing the exposure periods. The lowest malondialdehyde content was recorded for CA2 exposed for 120 days. Regarding the effect of interaction between storage temperatures and exposure period, data shows that malondialdehyde content for different exposure periods decreased as storage temperature increased. The lowest malondialdehyde content was noticed with 120 days exposure periods in room temperature.

Concerning to the interaction between storage temperature, controlled atmosphere and exposure period, it is obvious that the lowest malondialdehyde content (7.95) was recorded for 120 days exposure periods with CA2 at room temperature. On the other hand, the highest malondialdehyde content (24.75) was recorded for zero day exposure period in all controlled atmospheres in cold storage.

\section{Discussion}

It is well known that, fresh fruit and vegetables are living tissues that continue to lose water after harvest, but, unlike growing crops, they can no longer replace lost water from the soil and must rely on the water content present at harvest. The loss of water from fresh produce following harvest is a serious problem because it causes shrinkage and weight loss. So, most commodities become unsalable as fresh produce after losing 3-10\% of their weight. On the other hand, the quality and storage life of fresh produce are highly dependent upon the vapor pressure gradient between the produce and the storage atmosphere (Hung et al. 2011). Therefore, when the produce and the storage environment are maintained at the same temperature (assuming factors such as air velocity are held uniform), the transpiration rate is highly correlated with the relative humidity $(\mathrm{RH})$ during storage time. Transpiration through the actions of the stomata, lenticels, cuticles and epidermal cells is considered the major cause of postharvest weight loss and poor quality in leafy vegetables. For the commodity's transpiration, a high RH storage environment plays an important role in maintaining the quality of produce. Recommended $\mathrm{RH}$ levels for the storage of fresh fruit and vegetables are commodity specific, with levels generally in the range of 85-95\% (Hung et al. 2011).

A lot of attempts have been made by several workers in many crops to develop methods for maintaining the viability and vigour of seeds for longer period during storage. It is well known fact that the choice of materials for seed treatment, containers selected for storing the seeds and storage environment exert a positive effect on the viability and vigour of seeds in storage. The information on prolonging the shelf life of onion seeds under storage is very limited. A controlled atmosphere is essential for safe and long term storage of seeds. Environmental conditions which are safe for storage from harvest to planting are not necessarily safe for longer periods. The controlled storage is very essential especially in tropical and subtropical conditions to maintain high viability of seeds for longer periods (Nagaveni, 2005).

The deterioration (ageing) of seeds may begin before harvest and continues during harvest, processing and storage, at a rate greatly influenced by genetic, production and environmental factors. So, some of the deleterious effects of aging are associated with damages occurring at membrane, nucleic acids and protein levels. Peroxidation of unsaturated fatty acids is considered to be one of the main reasons for loss of storability, which occurs due to decreased level of antioxidants, reduce activity of free radical and peroxide scavenging enzymes, and increased lipid peroxidation, viz, malondialdehyde content (Chiu et al. 1995).

High $\mathrm{CO}_{2}$ and low $\mathrm{O}_{2}$ storage have been applied in ancient times. The earliest use of controlled-modified atmosphere storage may be attributed to the Chinese. Effect 
of atmosphere on ripening of fruits was determined in the early 1800s by Jacques Berard, a chemist at Montpellier Institute in France. Then, several further studies were made in the United States to research the effects of atmosphere on ripening of fruits (Salunkhe et al. 1991). The scientific beginning of controlled and modified atmosphere storage was in England by Kidd and West in the 1920s (Ryall and Lipton, 1979). Since its beginning, the studies on controlled atmosphere storage literature have grown enormously (Das, 2004). Controlled atmosphere storage is one of the food preservation methods that maintain the natural quality of food products in addition to extending the storage life. The storage life of food products is considerably extended by modifying the atmosphere surrounding the food, which reduces the respiration rate of food products and activity oxidation and insects or microorganisms in food (Jayas and Jeyamkondan, 2002).

In general, the controlled atmosphere is useful technique to store onion seeds to maintain high germination percent. The higher percent of $\mathrm{CO}_{2}$ decreased the infestation percentage and had lowered percentage fungal count, indicating the antifungal effect of $\mathrm{CO}_{2}$. This is a beneficial for retaining high germination percent. The results are similar to those results given by Rathi et al. (2000). These results are in agreement with those obtained by Shehata et al. (2009) on cowpea. They found that the germination percent of seed stored under controlled atmosphere is not less than $92 \%$.

Higher seed viability was observed after cold temperature storage compared with storage at room temperature. These results may be due to increasing the water and malondahyde content of onion seeds which stored at cold temperature than at room temperature. These results are in agreement with those of Yanping et al. (1999) as they reported that water content of the atmosphere is the most critical factor, a rise in air moisture being more damaging than raising temperatures. Concerning the effect of the interaction between storage temperature and controlled atmosphere, the highest germination percentage was recorded for CA2 at room temperature. The germination percentage decreased in all controlled atmospheres by decreasing the storage temperature.

Concerning the effect of the interaction between exposure period and controlled atmosphere on germination (\%), water content, and enzyme activities are presented in Table 1. All previous parameters were gradually decreased by increasing exposure period in all controlled atmospheres, whereas the malondialdehyde content increased. The lowest water content was recorded at CA2 exposed for 120 and 240 days. On the other hand, the highest water content was recorded for zero day exposure periods at $5^{\circ} \mathrm{C}$.

\section{Conclusion}

Storage of fresh fruits and vegetables prolongs their usefulness. The principal goal of storage is to preserve the commodity in its most useable form for the consumer.
The extension of storage life and the improvement of quality of fresh fruits and vegetables can be supplied by harvesting at proper maturity, control of postharvest diseases, chemical treatments, refrigeration, controlled and modified atmospheres. The main goals of storage are to slow the biological activity of fruits and vegetables, slow the growth of microorganisms and reduce transpiration losses. Controlled atmosphere storage can be defined as the storage of a commodity under an atmosphere that is different than air. The atmosphere is monitored and maintained through the term of storage. High $\mathrm{CO}_{2}$ and low $\mathrm{O}_{2}$ storage have been applied in ancient times. The earliest use of controlled-modified atmosphere storage may be attributed to the Chinese. Usually controlled atmosphere storage of vegetables employs a lower $\mathrm{O}_{2}$ concentration and higher $\mathrm{CO}_{2}$ concentration than normally found in air. Ideally, the rate of respiration of vegetables held under CA storage is lower than it would be under air. CA storage is particularly effective when vegetables are held under refrigeration. Such a system is exceptionally valuable for preserving high market value produce such as cauliflower, asparagus and broccoli. Under controlled atmospheric conditions, the atmosphere is modified from that of the ambient atmosphere, and these conditions are maintained throughout the storage. MAP uses the same principles as CA storage; however, it is used on smaller quantities of produce and the atmosphere is only initially modified.

The application of this research is concerned with the improvement of onion seed nutrition and management under saline conditions of Egypt as pre-harvest. At the same time, physiological and biochemical findings can be considered in onion seed storage under arid and semi-arid zones as post-harvest. Therefore, the pre-harvest and post-harvest treatments should be considered.

\section{References}

Amako, A., K. Chen and K. Asada (1994). Separate assays specific for ascorbate peroxidase and guaiacol peroxidase and for the chloroplastic and cytosilic isoenzymes of ascorbate peroxidase in plant. Plant Cell Physiology, 35: 497-504.

Basu, R. N. (1995). Seed viability. pp.1-44. In: Seed Quality, Basra A. S. (Eds.). Basic Mechanisms and Agricultural Implications, Food Products Press, New York.

Ben-Yehoshua, S. and V. Rodov (2003). Transpiration and water stress. Pp. 111 - 159. In: J. A. Bartz and J. K. Brecht (Eds.) Postharvest physiology and pathology of vegetables. Marcel Dekker, New York.

Chance, B. and A. C. Maehly (1955). Assay of catalase and peroxidase. Methods in Enzymology, 2: 764-775.

Chiu, K. Y., C. S. Wang and J. M. Sung (1995). Lipid peroxidation and peroxide scavenging enzymes associated with accelerated aging and hydration of watermelon seeds differing in ploidy. Physiol. Plant., No. 94: 441-446.

Christian, L., L. Irene, P. Esther and V. Miguel (2001). Short-term effects of air and controlled atmosphere storage on antioxidant metabolism in conference pears. J. Plant Physiol., No. 185: 1015 -1022 . 
Coolbear, P. (1995). Mechanisms of seed deterioration, pp. 223277. In: Seed Quality Basra A. S. (Eds.). Basic Mechanisms and Agricultural Implications, Food Products Press, New York.

Das, E. (2004). Effect of controlled atmosphere storage, modified atmosphere packing and gaseous ozone treatment on the survival characteristics of Salmonella enteritidis at cherry tomatoes. Master of Science in Food Engineering, the Graduate School of Natural and Applied Sciences, Middle East Technical Uni., India.

Demirkaya, M., K. J. Dietz and H. Ö. Sivritepe (2010). Changes in Antioxidant Enzymes during Ageing of Onion Seeds. Not. Bot. Hort. Agrobot. Cluj, Vol. 38 (1): 49-52.

FAO (2012). Major food and agricultural commodities and producers - Fao.org. http://faostat.fao.org/site/567/DesktopDefault. aspx?PageID=567\#ancor Retrieved 2012-07-22

Health, R. L. and L. Parker (1968). Peroxidation in isolated chloroplasts. 1. Kinetics and stoichiometry of fatty acid peroxidation. Arch. Biochem. Biophys., 125: 189-198.

Hung, D. V., S. Tong, F. Tanaka, E. Yasunaga, D. Hamanaka, N. Hiruma and T. Uchino (2011). Controlling the weight loss of fresh produce during postharvest storage under a nano-size mist environment. Journal of Food Engineering, Vol. 106: 325-330.

Jayas, D. S. and S. Jeyamkondan (2002). Modified atmosphere storage of grains, meats, fruits and vegetables. Biosystem Engineering, 82(3): 235-251.

Korkmaz, A., N. Ozbay and B. Eser (2004). Assessment of vigor characteristics of processing tomato cultivars by using various vigor tests. Assian Journal of Plant Sciences, 3(2): 181-186.

Kurubar, L. (2005). Post-harvest studies in onion Cv. N- 53. Ph. D. Thesis, Department of Horticulture, College of Agriculture, University of Agricultural Sciences, Dharwad- 580 005, India.

McDonald, M. B. (2004). Orthodox seed deterioration and its repair, pp. 273-304. In: Handbook of Seed Physiology: Applications to Agriculture. Benech-Arnold, R. L. and R.A. Sanchez (Eds.). Food Products Press, New York

Muhammad, A. and M. A. Anjum (2002). Effect of relative humidity and ageing on the quality of onion seed. International Journal of Agriculture and Biology, 4(2): 291-296.

Nagaveni, P. K. (2005). Effect of storage conditions, packing materials and seed treatment on viability and vigour of onion seeds. M.Sc. in Seed Science and Technology Dept., University of Agricultural Sciences, Dharwad, 580 005, Dharwad, India.

Pablo, J. T. F., F. N. Jacqueline and B. W. Christopher (2007). Antioxidant enzyme activities in strawberry fruit exposed to high carbon dioxide atmospheres during cold storage. Food Chemistry, Vol. 104: 1425-1429.

Rao, R. G. S., P. M. Singh and M. Rai (2006). Storability of onion seeds and effects of packaging and storage conditions on viability and vigour. Scientia Horticulturae, No. 110: 1-6.

Rathi, S. S., N. G. Shan, S. S. Zambre, V. H. Kalbande and K. V. Ventkatesh (2000). Respiration, sorption and germination of seeds stored in controlled atmosphere. Seed Science and Technology, 28: 341-348.

Ryall, L. A. and W. J. Lipton (1979). Handling, Transportation and Storage of Fruits and Vegetables, Vol. 1, Vegetables and Melons, Avi Publishing Company, Inc., Westport, Connecticut.

Salunkhe, D. K., H. R. Bolin and N. R. Reddy (1991). Storage, Processing and Nutritional Quality of Fruits and Vegetables, Vol. 1, Fresh Fruits and Vegetables, CRC Press, Inc., Boston.

Selvaraj, S. (1976). Onion: Queen of the kitchen. Kisan World, 3(12): 32-34.

Shehata, S. A., M. Y. Hashem, K. F. Abd El-Gawad (2009). Effect of controlled atmosphere on quality of dry cowpea seeds. $4^{\text {th }}$ Conference on Recent Technology in Agriculture. Faculty of Agriculture, Cairo University, pp: 635- 649.

Shehata, S. A., M. Y. Hashem, G. I. Mahmoud, K. F. Abd ElGawad, H. R. El-Ramady, T. A. Alshaal, É. Domokos-Szabolcsy, N. Elhawat, J. Prokisch and M. Fári (2013). Effect of foliar nutrition on postharvest of onion seed under sandy soil and saline irrigation water conditions. International Hungarian Journal for Horticulture (in press).

Waller, R. A. and D. B. Duncan (1969). A bays rule for the symmetric multiple comparison problems. Amer. Stat. Assoc. J., 64: 1485-1503.

Yanping, Y., G. Rongqi, S. Qingquan and L. Shengfu (1999). Effects of storage temperature and container type on the vigour of Welsh onion seeds with low moisture content. Australian Journal of Experimental Agriculture, 39(8): 1025-1028.

Yasseen, M. Y. (1994). Studies on onion seed aging. Proceedings of the Florida State Horticultural Society, 106: 255-257. 